\section{MIT's Amazon outpost}

São Paulo. The US Massachusetts Institute of Technology (MIT) has agreed to provide technical backing for a US\$5-million project designed to stimulate the growth of a biotechnology industry based on the biological and genetics resources of Brazil's Amazon region.

An agreement to collaborate was signed last month between the institute, the governor of the state of Amazonas and the director of a newly created biotechnology laboratory, the Centro de Biotecnologia da Amazônia (CBA), in the state capital Manaus.

Under the terms of the agreement, whose initial phase will last for three and a half years, MIT researchers from disciplines such as microbiology, enzymology and biochemical engineering will help to develop new techniques appropriate to the resources and economic interests of the region.

Initial activities will concentrate on areas such as agriculture, fishing and cattle breeding. At a later stage, however, attention will also be given to the more controversial area of screening the Amazon region's flora and fauna for pharmaceuticals.

MIT officials compare the potential significance of the new agreement to that provided several decades ago by the institute to the state of São Paolo, which helped to create Brazil's now flourishing aircraft construction industry.

Brazilian scientists say that one important characteristic of the new initiative is that, unlike deals struck by other countries with foreign companies, it will include agreement that any commercially important genetic resources discovered in the region will be developed locally, rather than outside Brazil.

"The idea is not to do what Merck did to Costa Rica", says Isaias Raw, head of the Butantan Institute of São Paolo. Referring to a deal with the pharmaceutical company

\section{IMAGE UNAVAILABLE FOR COPYRIGHT REASONS}

Genetic resources for local industry?
Inbio, he compares Costa Rica to the woman played by Demi Moore in the film Indecent Proposal, who agrees to sleep with actor Robert Redford for \$1 million.

"Just cataloguing plants will not lead you anywhere", says Raw. "Scientists in Amazonia should start using biotechnology to exploit the region's biodiversity."

The creation of the laboratory has been one of the first tasks of a new foundation, the Foundation for Conservation of the Biodiversity of Amazonia (FCBA), which has been set up at the initiative of the state governor, Gilberto Mestrinho.

In the past, Mestrinho has been strongly criticized both within and outside Brazil because of his staunch defence of the economic development of Amazonia, and for paying insufficient attention to the need to conserve the environment.

The new foundation, set up at a time when the idea of "sustainable development" popularized at last year's Earth Summit in Rio de Janeiro is one everyone's lips, is intended to counter this image. "We hope to carry on scientific and technological research within a conservationist philosophy", says Raimar da Silva Aguiar, the state's secretary for planning, who played an important part in setting up the foundation.

The stated objective of the foundation is to "keep centres of excellence directed towards seeking development alternatives for the state of Amazonas and the region". Seed money of $\$ 500,000$ has already been raised from private enterprises, including mining, construction and biomedical companies, as well as the Brazilian branches of Sharp and Semp-Toshiba.

The foundation has promised to make as much use as possible of resources already existing in the region, providing support not merely to the biotechnology centre but also local institutions such as the National Institute of Amazon Research (INPA), universities and the agricultural research units of the Brazilian Ministry of Agriculture.

The new laboratory being funded by the foundation has already been given a building in Manaus by the state of Amazonas. It will draw on the experience of researchers from the south of Brazil who have organized a similar centre at Porto Alegre, in the state of Rio Grande do Sul. Much of the impetus for its research programmes, however, will come from the visiting MIT researchers, who will assist with both teaching personnel and technology transfer.

Anthony Sinskey, associate director of the institute's Biotechnology Process Engineering Centre and one of the leaders of the project, says he hopes MIT will profit from the opportunities for research in what is relatively virgin territory, as little modern biotechnology research has been done in the region. "It should open new intellectual questions and frontiers in science and engineering", says Sinskey.

According to Brazilian scientists, the foundation is expected to take the largest share of any royalties and patents derived from research in the laboratory. "But obviously MIT will have a share in things developed jointly", says Diogenes Santos, the founder of the biotechnology centre in Porto Alegre.

FCBA officials say they are open to cooperation agreements with other foreign institutes besides MIT. But they insist that the research has to be carried out in Brazil. Many remember the country's experience with rubber, which is native to Amazonia, but which was exploited in other parts of the world. "If you do not do research in the country, nothing stays here," says Raw.

Ricardo Bonalume Neto

\section{Money-saving space station plan}

Washington. US and Russian space agencies have agreed to work together on developing a joint international space station which that incorporate the main elements of current designs for both the US Freedom station and the proposed Russian Mir 2.

Officials at the US National Aeronautics and Space Administration (NASA) say that the joint station, plans for which are to be produced by 1 November, could use Mir as an initial building block. Such a move would speed up the overall programme by two years, and as a result could save the United States a substantial amount of money.

But the agreement, signed in Washington last week by US vice-president Albert Gore and Prime Minister Victor Chernomyrdin, also means that recently completed plans for a redesigned US space station - due to be presented by NASA to President Bill Clinton this week - will be subject to still further extensive revision in November.

Fortunately for NASA, details of the USRussian space station will not be ready until after Congress has approved funding for the US space station for the coming fiscal year. It is the details that will determine which NASA contractors are likely to lose work to Russia under the deal, and such knowledge could result in lost votes for the programme.

The existing partners on the US space station - Europe, Canada and Japan - are being kept informed of the progress of discussions. But they are not being directly involved in negotiating the deal, and will effectively have to accept it as a fait accompli.

The United States has also promised to pay Russia $\$ 400$ million over the next four years for using existing Russian facilities in cooperative space programmes. Programmes in which the two countries plan to collaborate include sending US astronauts to the existing Mir 1 station, and developing a joint space suit.

Colin Macilwain 